\title{
Towards a new approach in the study of Ancient Greek music: Virtual reconstruction of an ancient musical instrument from Greek Sicily
}

\author{
Angela Bellia (D) \\ Institute for Archaeological and Monumental Heritage, National \\ Research Council of Italy
}

\section{Abstract}

In the summer of 2012, the Institute of Fine Arts, New York University Selinunte Mission began to explore the interior of the cella of Temple R. This excavation showed that the classical and archaic layers had been sealed by a deep fill of the Hellenistic period and left untouched by earlier archaeological research at the site. Among the discoveries were a series of votive depositions positioned against the walls, dating to the sixth century BCE. One of the most striking finds among

Correspondence:

Angela Bellia, Institute for

Archaeological and

Monumental Heritage,

National Research Council

of Italy, c/o Palazzo Ingrassia

- via Biblioteca, 4 - 95124

Catania.

E-mail:

angbellia@gmail.com or angela.bellia@unibo.it those votive depositions was the discovery of two parts of a bone aulos, which can be dated to $570 \mathrm{BCE}$. The virtual reconstruction of the aulos found in Temple R at Selinunte aims to increase and improve its scientific investigation, overcoming the limitations caused by the fragility of the instrument. Digital technology has allowed us to produce a three-dimensional (3D) model of the aulos. This digital model has been translated into a 3D artificial copy, using polymer as a material. Our goal is to reconstruct the aulos, after analysing its organological characteristics. We also hope that this new study of the aulos will increase our knowledge of Ancient Greek music.

\section{Introduction}

The discipline of archaeomusicology is based on analyses of ancient depictions of music and finds of musical instruments in their archaeological context, rather than in isolation. This is the research methodology and approach of the TELESTES project, which has been funded by the European Commission's Marie Curie Actions programme. ${ }^{1}$ This project is dedicated to the musical culture of Selinus (modern Selinunte), one of the most important western Greek cities. In 2007, the Institute of Fine Arts at New York University, in collaboration with the Superintendency of Trapani and the Archaeological Park of Selinunte, initiated a project of topographical, architectural, and archaeological investigation of the main urban sanctuary on the Acropolis in Selinunte, under the direction of Clemente Marconi (Marconi, 2013; Marconi and Scahill, 2015).

A very important part of the TELESTES project is the study of an actual aulos that was discovered in two pieces under Temple R. In the summer of 2012, the Institute of Fine Arts, New York University 


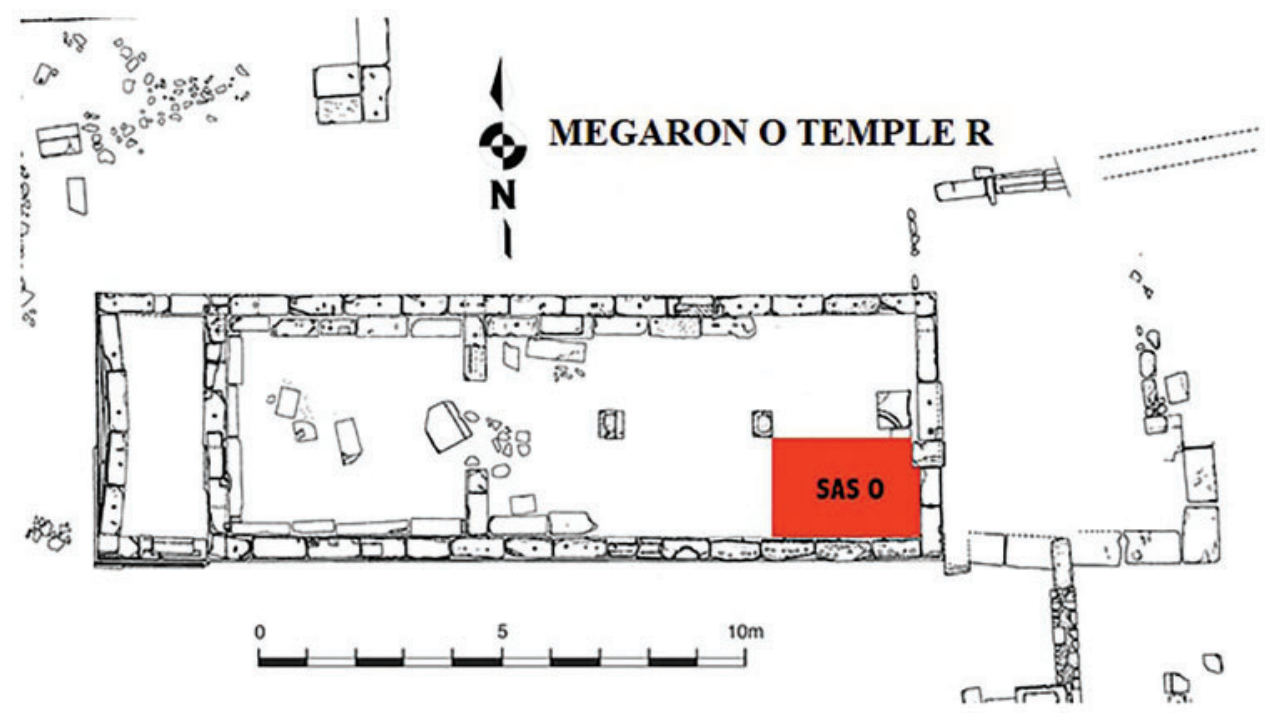

Fig. 1 Selinunte, state plan of Temple $\mathrm{R}$ with indication of Trench $\mathrm{O}$ (C) Institute of Fine Arts, NYU.

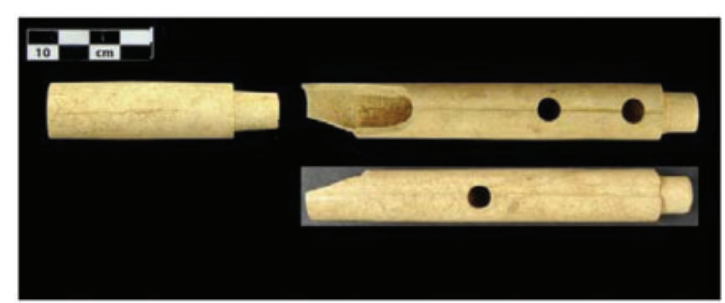

Fig. 2 Selinunte, Temple R: Aulos fragments. Museum 'Baglio Florio' of Selinunte. Cons. 12.84 Photograph by Raffaele Franco.

(C) Institute of Fine Arts, NYU.

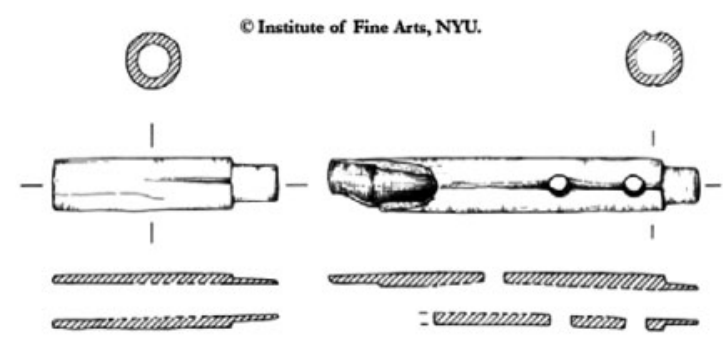

Fig. 3 Selinunte, Temple R: Aulos fragments. Drawing by Filippo Pisciotta

(C) Institute of Fine Arts, NYU.

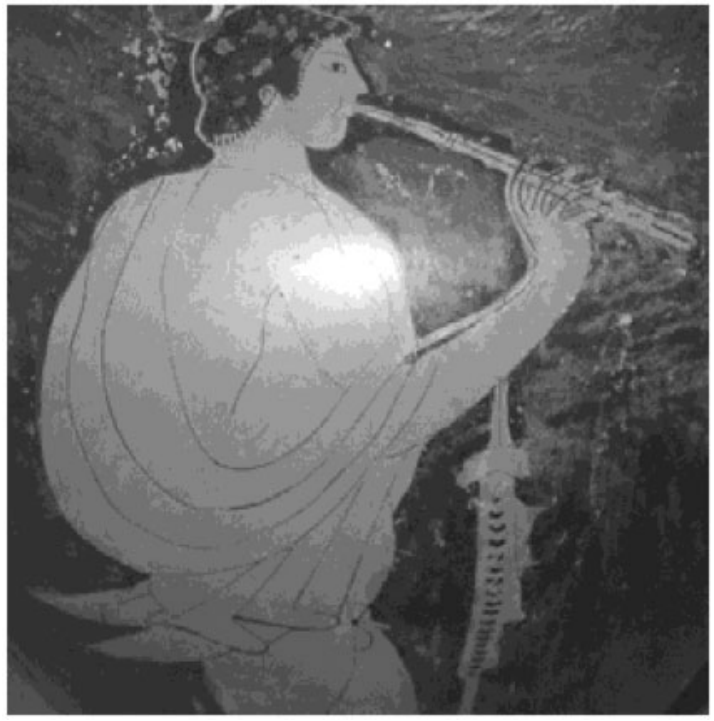

Fig. 4 Aulos player. Detail from red-figure amphora in Palermo early fifth c. BCE (N.I. 2045)

Selinunte Mission began to explore the interior of the cella of Temple R (Fig. 1). This excavation showed that the classical and archaic layers had been sealed by a deep fill of the Hellenistic period 


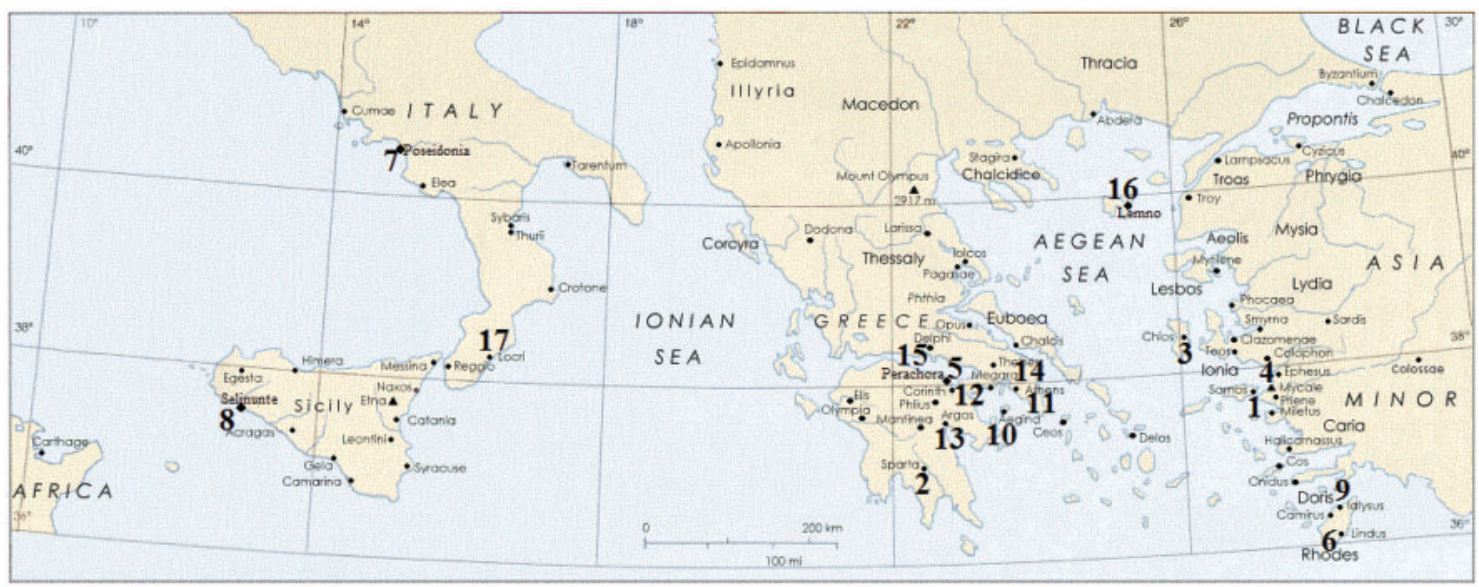

Fig. 5 (1) Samos (VII c. BCE); (2) Sparta (VII c. BCE); (3) Chios (630-600 BCE); (4) Ephesus (600-550 a.C.); (5) Perachora (600-550 BCE); (6) Lindos (VI c. BCE); (7) Poseidonia (VI c. BCE); (8) Selinunte (VI c. BCE); (9) Ialyssos (VI-V c. BCE); (10) Aegina (VI c. BCE); (11) Brauron (ante 480 BCE); (12) Corinto (V c. BCE); (13) Argos (V c. BCE); (14) Athens (ante 480 BCE); (15) Delphi (V c. BCE); (16) Lemno (V c. BCE); (17) Locri (V c. BCE?)

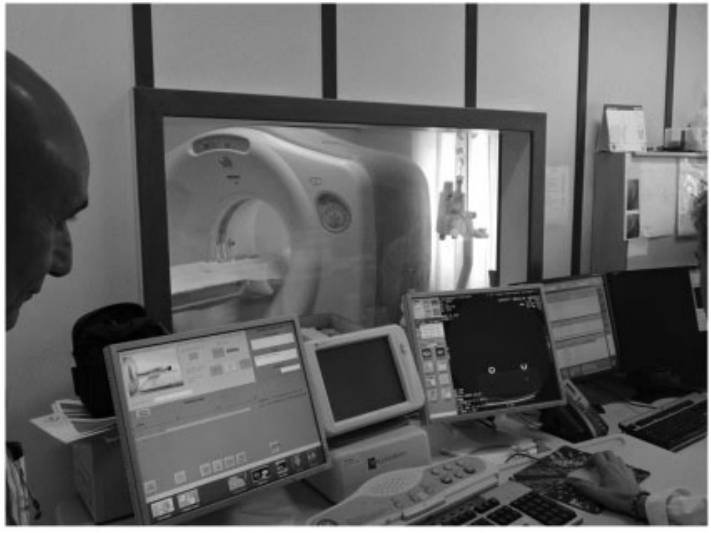

Fig. 6 Computed axial tomography. Photograph by Angela Bellia

and left untouched by earlier archaeological research at the site. Among the discoveries was a series of votive depositions against the walls, dating back to the sixth century BCE. One of the most striking finds among the votive depositions positioned was the discovery of two parts of a bone aulos, held today at the Museum 'Baglio Florio' of Selinunte, which can be dated to 570 BCE (Figs. 2-3).

The aulos was a widely used wind instrument with finger holes and a reed mouthpiece (Bellia 2009) (Fig. 4). In the archaic and classical

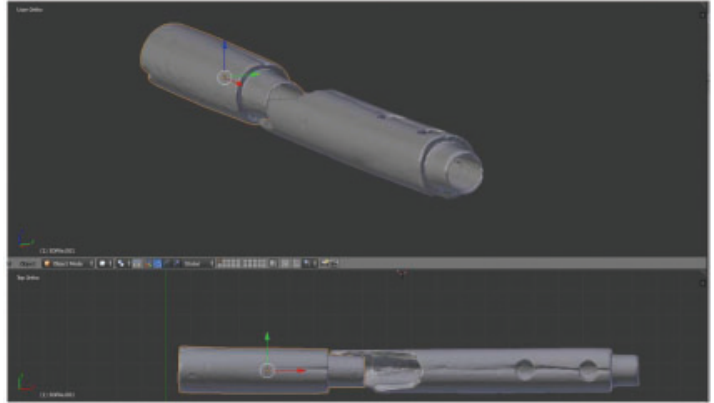

Fig. 7 Computed axial tomography of the aulos

periods, the aulos was characterized by the absence of mechanisms of action on the holes for sound production. These are so-called 'early type' auloi, conventionally named to distinguish them from later versions, which have keys to change their sound. The use of this type of auloi extends to the Hellenistic age. They were played exclusively by covering the holes in the upper part of the two reeds with fingers (either in alternation or by covering all holes at the same time) and, when present, by covering the thumbhole placed at the back of the tubes. Early-type instruments were usually of different lengths: the earliest versions in bronze and wood were made up of two sections, and the later bone versions were made up of four (West, 1992). 


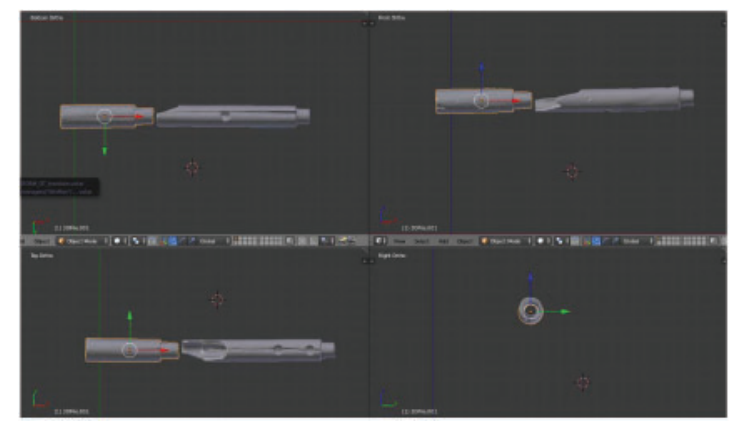

Fig. 8 The two sections of the aulos

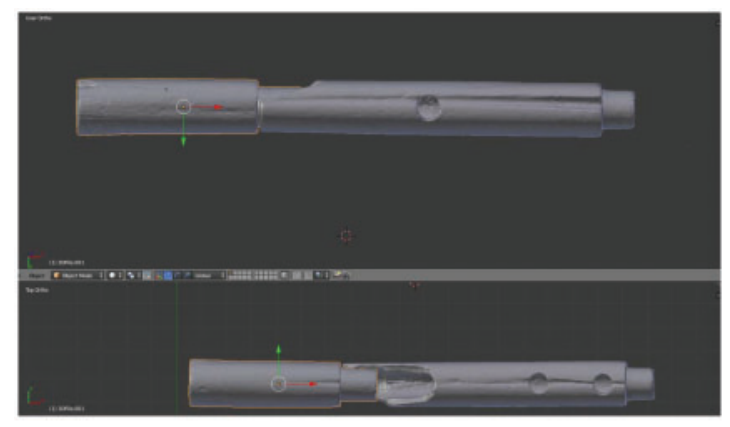

Fig. 9 The two sections of the aulos fit together

With regard to the present state of the studies, the sacred contexts of the 'early type' auloi (Psaroudakēs 2002), or their sections, refer to Hera at Samos (Moustaka, 2001), Chios (Boardman, 1967), Perachora (Dunbabin, 1962; Psaroudakēs, 2013), and Poseidonia (Greco, 1998; Greco, 1999); to Artemis at Sparta (Dawkins, 1939), Ephesus (Hogarth, 1908; Psaroudakēs, 2002), Brauron (Landels, 1963; Landels, 1999), and Aegina (Furtwängler, 1906); to Athena at Lindos (Blinkenberg, 1931; Psaroudakēs, 2008) and Iallyssos (Psaroudakēs, 2002; Psaroudakēs, 2013); and to Persephone at Locri (Bellia, 2012). Now we can add to these instruments the fragment of the aulos discovered in Selinunte in the sanctuary of 'Malophoros' (Bellia, 2017), and the two sections found under Temple $\mathrm{R}$, probably dedicated to Demeter 'Thesmophoros' (Marconi, 2014; Bellia, 2015) (Fig. 5).

This discovery at Selinunte is very significant, particularly with regard to the performance of music and

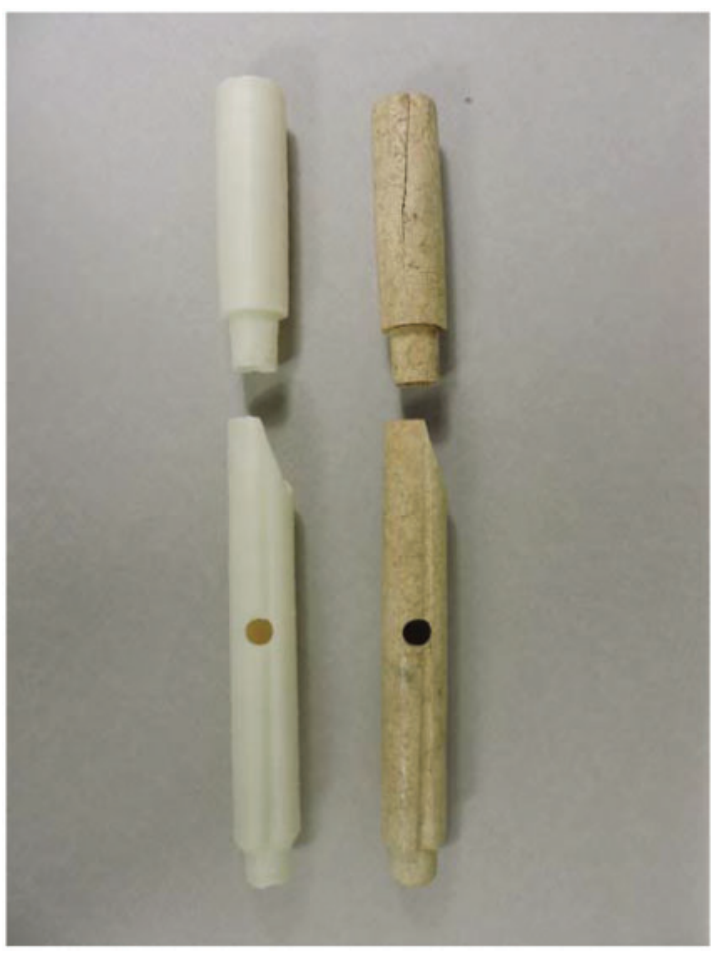

Fig. 10 Second finger hole for the thumb on the underside of the pipe

ritual dancing associated with the cult activity of Temple R. As Clemente Marconi has argued, the performance of choral dancing in this part of the main urban sanctuary of Selinus is also suggested by the discovery of a series of fragments of Corinthian vases in the area of Temple $\mathrm{R}$ feature chains of dancing women that conform to the so-called 'Frauenfest' iconography. These discoveries show the importance of music and dance at Selinus as early as the early archaic period (Marconi, 2013; Marconi, 2014; Marconi and Scahill, 2015).

The on-going study of the musical instrument from Selinunte is relevant both for its organology and for the information offered by the analysis on the type of bone used in its production. The threedimensional (3D) virtual reconstruction of the aulos from Selinunte is aimed not only at the acoustic and morphological study, but also to increase and improve the instrument's scientific investigation. 

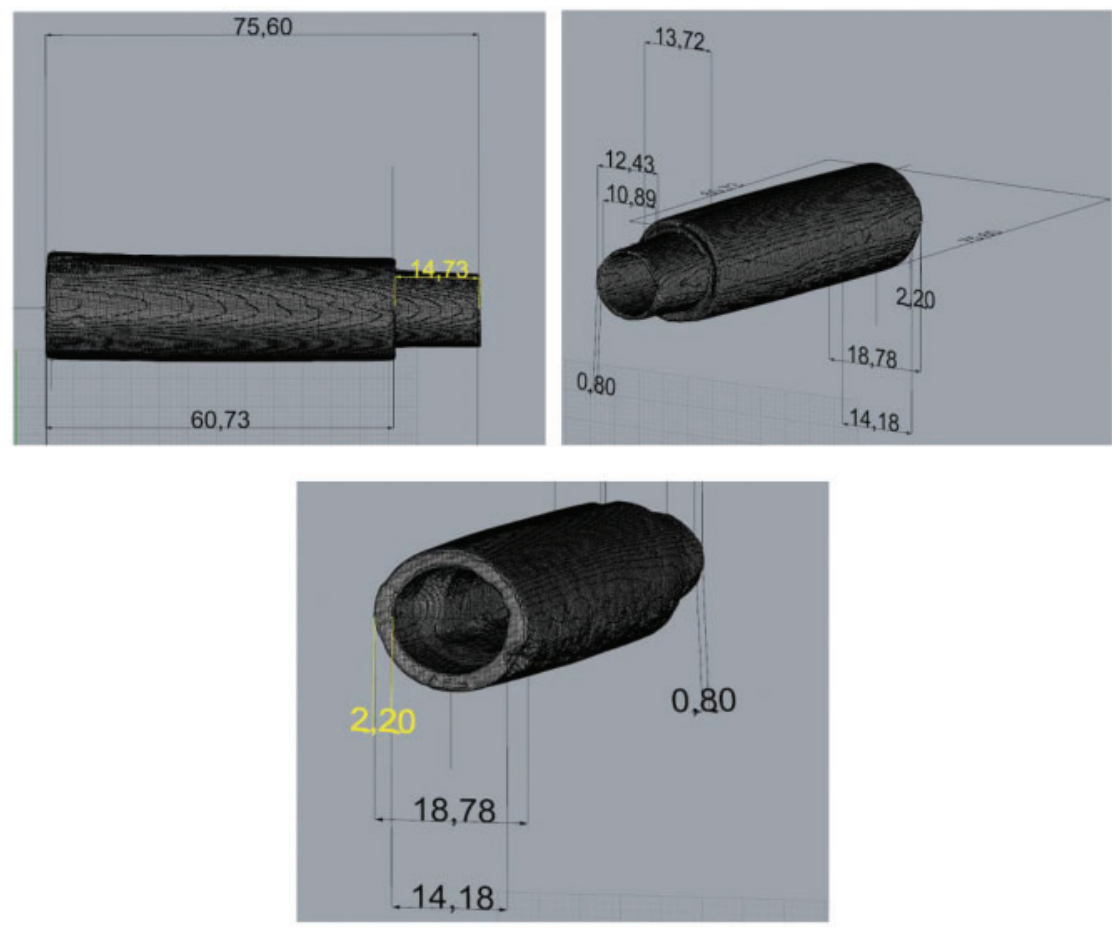

Fig. 11 Measurements of the Section A

\section{Computed Axial Tomography}

The lost parts of the instrument included the other pipe. To render a virtual reconstruction of the aulos from Selinunte, we are currently engaged in the project by several means. The first is that of a computed tomography (CT) scan of the bone, which has permitted the study of its measures and morphology, overcoming the limitations presented due to the fragility of the instrument (Fig. 6). Furthermore, the CT represents an accurate method for the visualization and analysis of surfaces, volumes, internal structure, and the material density of the ancient musical instrument. The aim is to use $3 \mathrm{D}$ scanning for generating 3D models of ancient musical instruments (Avanzini et al., 2015, 2016). We also aim to develop specific tools suitable for processing the resulting 3D models. The tools we are developing are divided into those involving the use of computational methods for processing the $3 \mathrm{D}$ models and those involving the development of interactive tools aimed at engaging museum visitors in the exploration of musical instruments (Micheloni et al., 2016) (Figs. 7-9). Among a variety of applications, a rotating $3 \mathrm{D}$ reconstruction of the aulos can be generated, showing possible damages, and the necessary repairs and modifications.

Within this framework, information from the undamaged parts of the object was utilized in combination with literary and iconographic sources, in an attempt to re-create the appearance of the complete object and group various fragments together.

\section{Measurements}

The exterior surface retains the natural shape of the bone from which the instrument was made, including the grooves, present on both pieces and cutting right across the finger holes and the thumbhole on the longer piece. Assuming that the two sections fit together with one another, the instrument is still incomplete. The lost portions would include the mouthpiece and the lower section with additional 

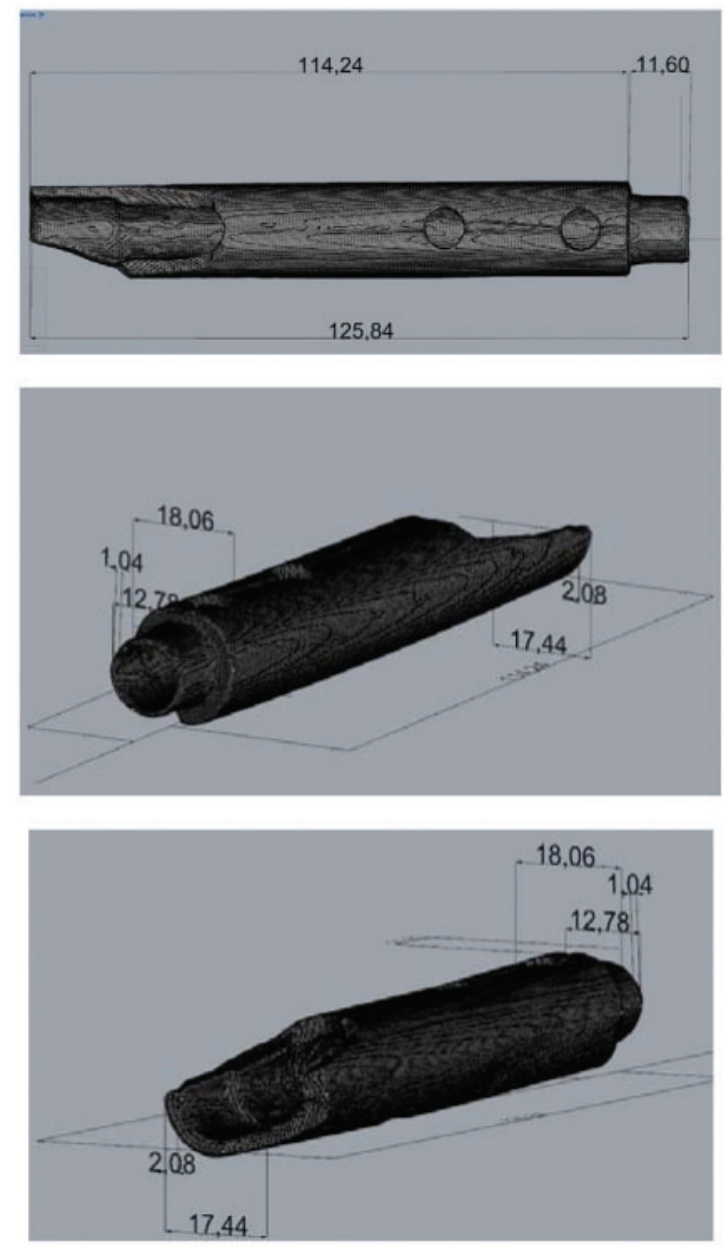

Fig. 12 Measurements of the Section B

finger holes. Bore and pipe workmanship is compatible with the use of an arched or rope drill used in antiquity by craftsmen to pierce the surfaces of objects. It is necessary to take in account that the second finger hole for the thumb (counting from the mouthpiece end) was on the underside of the pipe to the left, away from the hand, because the tube was the left member of its pair (Fig. 10).

To refine the measurements, a CT scan was used. The scanning was then read with the open-source software Horos, a medical image viewer that also provides tools to extract reliable measures from CT scans.

1. Measurements of Section A (Fig. 11)

Overall length of the section: $75.60 \mathrm{~mm}$

Operating length: $60.73 \mathrm{~mm}$
Length of the downstream spigot: $14.73 \mathrm{~mm}$

2. Measurements of Section B (Fig. 12)

Overall length of the section: $125.84 \mathrm{~mm}$

Operating length: $114.24 \mathrm{~mm}$

Length of the downstream spigot: $11.60 \mathrm{~mm}$

3. Distances of holes from upstream end and their diameters (Fig. 13)

4. Assemblage of sections (Fig. 14)

Overall length of the Sections A + B: $187.78 \mathrm{~mm}$

\section{The printed copy of the instrument}

Digital technology allowed us to produce a 3D model of the aulos. This digital model has been translated into a $3 \mathrm{D}$ artificial copy, using polymer as a material (Zoran, 2011) (Fig. 15). The digital model of the aulos has been translated into two 3D artificial copies at the School of Science and Engineering at the State University of New York at New Paltz, and at the Officina 3D Lab at Reggio Emilia (Fig. 16). The Officina 3D Lab also produced two video clips of the reconstruction of the aulos from Selinunte (Fig. 17). In addition to a polymer copy, on the basis of the measurements provided by the Computed Tomography of the instrument, Pitano Perra, an Italian wind instrument maker, reconstructed two reed and bone copies of the aulos (Fig. 18). ${ }^{2}$

The goal is to reconstruct the instrument, and to analyse its organological characteristics. However, because the upper end and the lower part of the aulos are missing, the possible pitches can only be deduced indirectly, by finding the instrument length with which the finger holes would yield a plausible scale. Although this principle seems promising, it will not be able to provide convincing results regarding the aulos from Selinunte, as we have just a single pipe. For this reason, the preserved aulos from Selinunte must be subjected to closer examination based on comparisons with other similar instruments and 'early type' auloi. The aulos from Selinunte conforms to the auloi 'early type' version found in the sanctuaries of Artemis Orthia at Sparta (dated to the end of the seventh century BCE) and Artemis at Brauron (dated to the sixth-fifth centuries $\mathrm{BCE}$ ), the examples found at Aegina in the 
Towards a new approach in the study of ancient music: Virtual reconstruction of a musical instrument from Greek Sicily

\begin{tabular}{|c|c|c|c|}
\hline Hole & distance ( $\mathrm{mm}$ ) & $\mathrm{d}_{\mathrm{x}}(\leftrightarrow \mathrm{mm})$ & $\mathrm{d}_{\mathrm{y}}(\Uparrow \mathrm{mm})$ \\
\hline I & 32.96 & 9.9 & 9.9 \\
\hline $\mathrm{T}$ & 56.44 & 7.54 & 7.99 \\
\hline II & 74.57 & 7.84 & 8.18 \\
\hline III & 105.19 & 7.57 & 8.29 \\
\hline
\end{tabular}
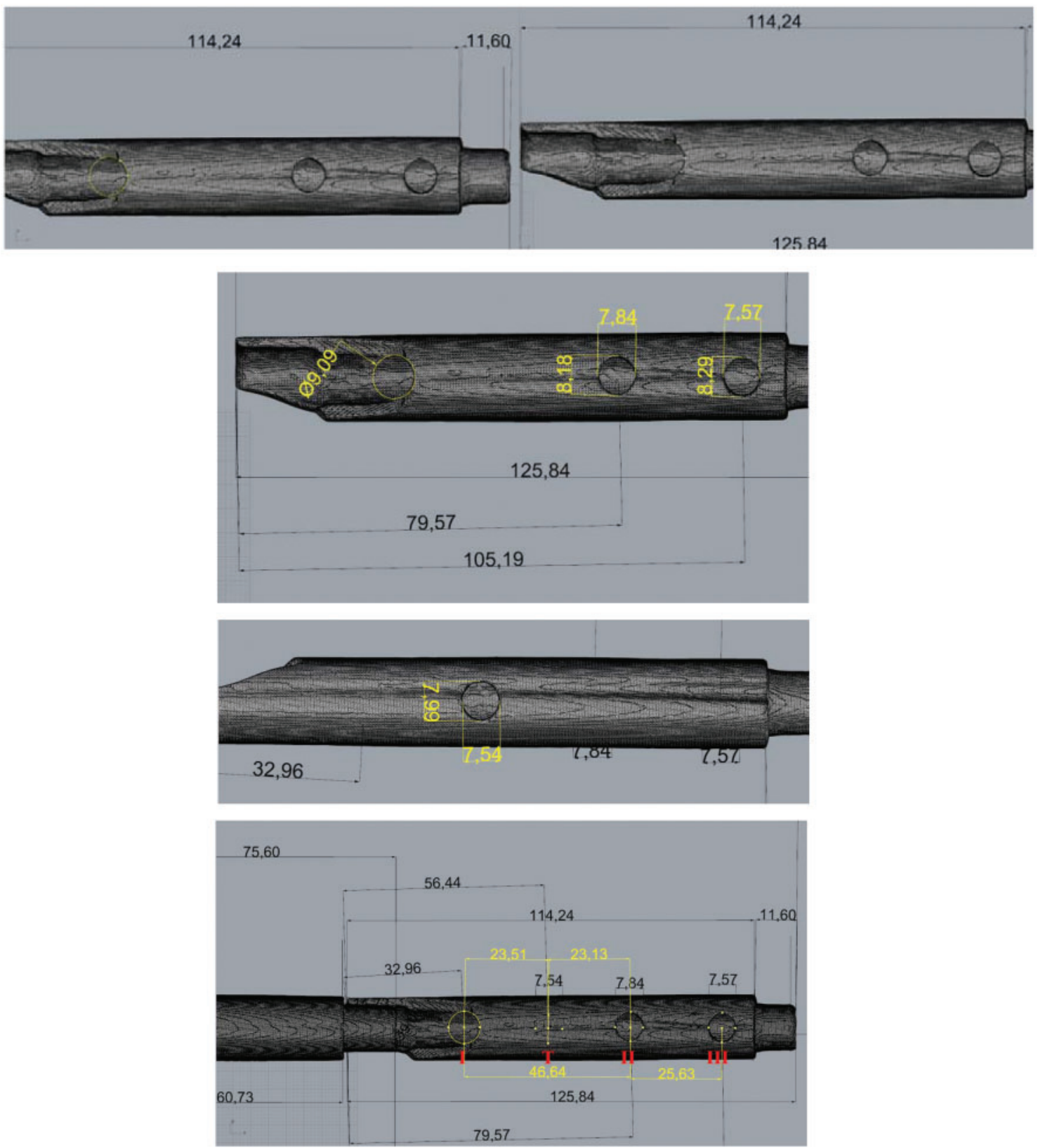

Fig. 13 Distances between holes from upstream end of the section and their diameters 


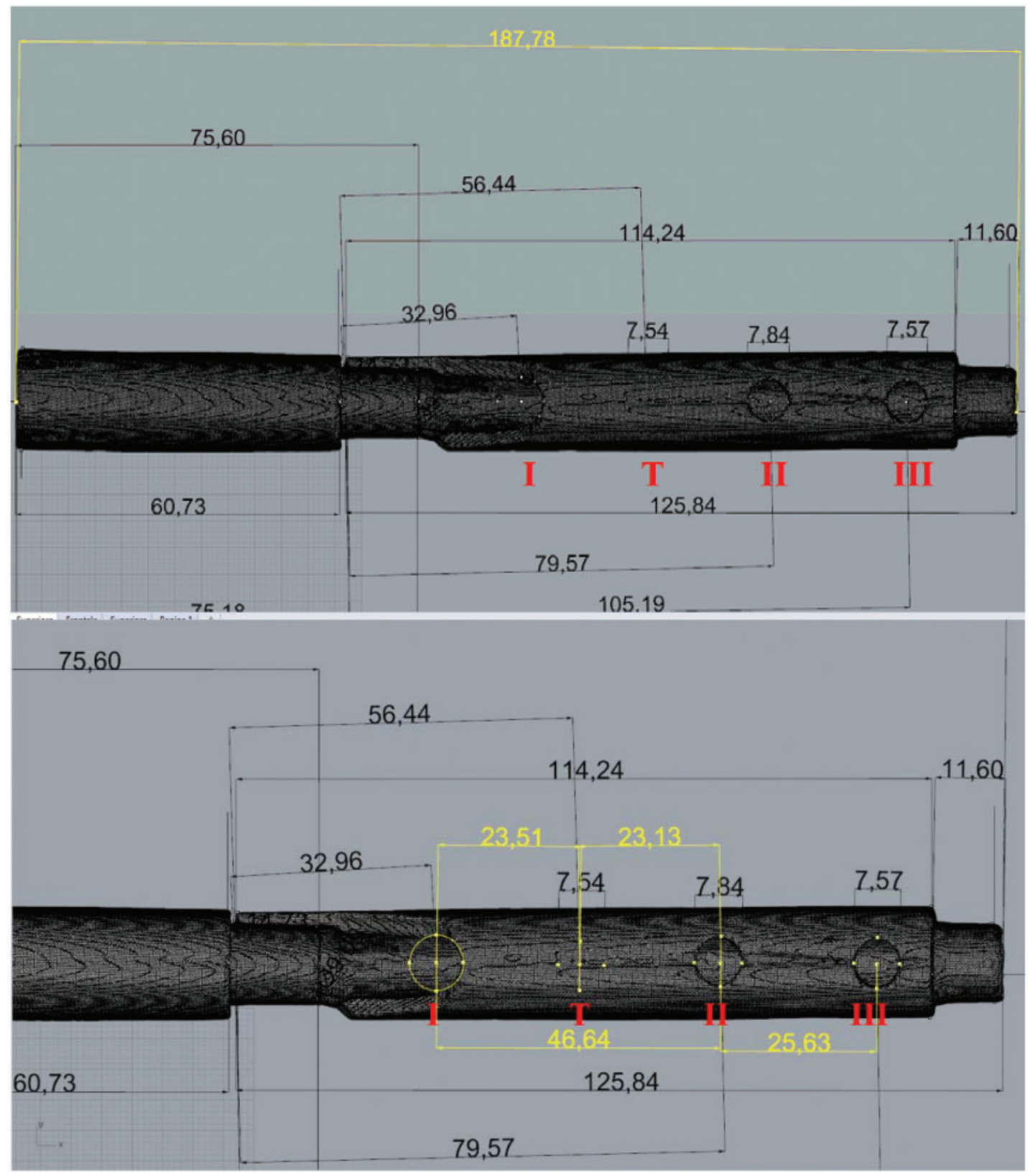

Fig. 14 Assembled sections of the aulos

sanctuary of Aphaia, and those from the sanctuary of Persephone at Locri Epizephyrii.

It is especially similar in form and date to an aulos found in a tomb at Poseidonia in southern Italy, which dates from the end of the sixth to the beginning of the fifth century BCE (Psaroudakês, 2014). It is a well-preserved 'early type' Greek aulos made of deer bone, housed today at the National Archaeological Museum of Paestum (Fig. 19). On the basis of the measurements of 


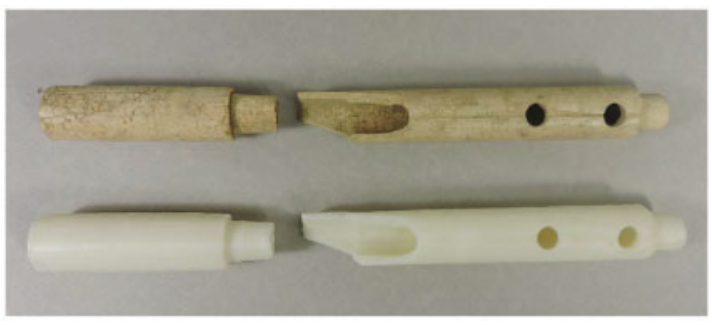

Fig. 15 The aulos from Selinunte and its 3D artificial copy

Photograph by Angela Bellia.

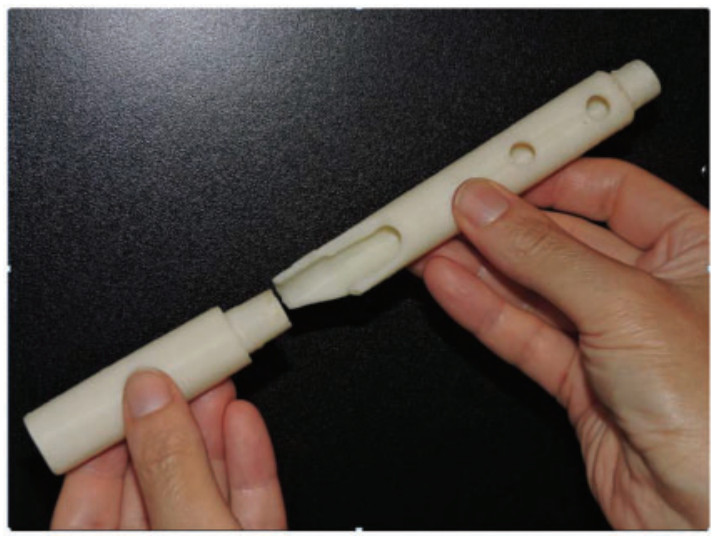

Fig. 16 Polymer copy of the aulos from Selinunte

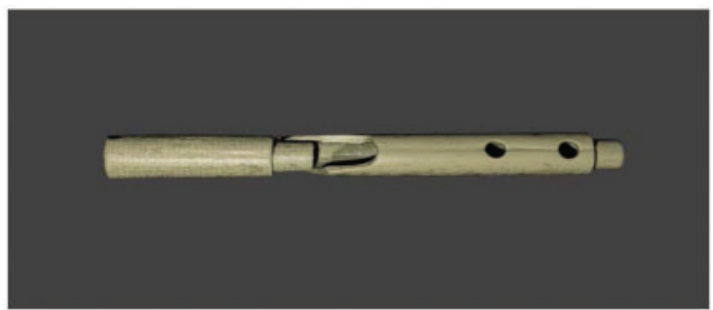

Fig. 17 Video of the aulos

this well-preserved and near-complete aulos from Poseidonia, the next step will be to reconstruct the incomplete tube of the aulos from Selinunte.

\section{Conclusion}

This study contributed towards overcoming limitations posed by traditional methods of measuring

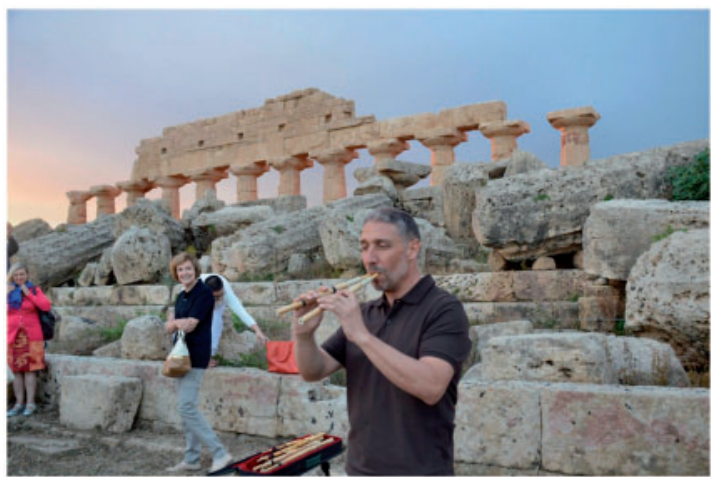

Fig. 18 American Archaeological Mission at Selinunte, in Sicily. Pitano Perra, an Italian wind instrument maker, is playing the reconstructed ancient instrument in the same place of its discovery. The instrument has been reconstructed on the bases of the digital model translated into a $3 \mathrm{D}$ copy using polymer as a material

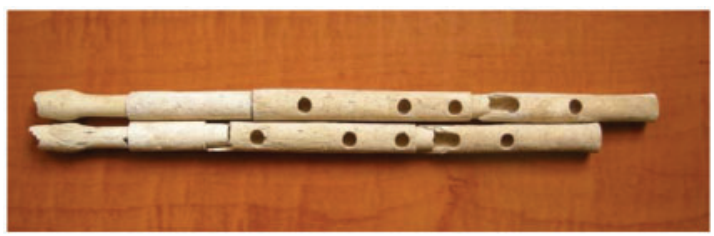

Fig. 19 The aulos of Poseidonia. Museum of Paestum. Inv. 23068

Photograph by Stelios Psaurodakes.

ancient musical instruments through pictures and drawings, opening up new perspectives for the study of the materials, origins, diffusion, and production process of musical instruments in antiquity. Moreover, according to the anthropologist Roberto Miccichè, the tubes were crafted from the metatarsal of a deer, a conclusion that was corroborated by the CT scan. The osteoarchaeological results open up new perspectives for the study of the materials, origins, diffusion, and production process of musical instruments in antiquity. As Pollux (Onomasticon, IV, 7d) recalls for Theban wind instruments, the bones of the chamois or roe deer legs were used for the production of the auloi. As it is a material that involved a complex manufacturing process, it can be assumed that the aulos could have been considered a precious object, more so if it was imported to Selinunte from the motherland Megara. 
The hypothesis of a provenance of the aulos from the motherland can be accounted for due to the presence of auloi manufacturers in Megara, whose activity must have had a long and well-established tradition if they were able to introduce innovations to the instruments: in this regard, it is interesting that Telefane of Megara in IV c. BCE (PseudoPlutarch, De Musica, XIV, 1137f-1138a) prevented the artisans from inserting additional holes into their instruments to modify their sound. It was for this reason that he was excluded from the Pythian Games, as he would have had to perform with the modified auloi.

In conclusion, this research will develop a new theoretical basis, which will contribute to the establishment of a methodology at the crossroads of archaeomusicology and digital technologies.

\section{Funding}

This research was funded by the European Commission's Marie Curie Actions. Project ID: 622974. Funded under: FP7-PEOPLE.

\section{Acknowledgement}

I would like to thank Professor Clemente Marconi, James R. McCredie Professor in the History of Greek Art and Archaeology at the Institute of Fine Arts at New York University, for granting me permission to study the aulos. I would also like to thank the anthropologist Dr Roberto Micciché for his suggestions and Dr Marco Orlandi for helping in the aulos measurements.

\section{References}

Avanzini, F., Canazza, S., De Poli, G., Fantozzi, C., Pretto, N., Rodà, A., Angelini, I., Bettineschi, C., Deotto, D., Faresin, E., Menegazzi, A., Molin, G., Salemi, G., and Zanovello, P. (2015). Archaeology and virtual acoustics: a pan flute from ancient Egypt. In Proceedings of the 12th International Conference on Sound and Music Computing Conference (SMC-15), Maynooth, Ireland, July 30, 31 \& August 1, 2015. http://www.dei.unipd.it/ avanzini/downloads/paper/ avanzini_smc15.pdf

Avanzini, F., Canazza, S., De Poli, G., Fantozzi, C., Micheloni, E., Pretto, N., Rodà, A., Gasparotto, S., and Salemi, G. (2016). Virtual reconstruction of an ancient Greek pan flute. In Proceedings of the 13th International Conference on Sound and Music Computing Conference (SMC-2016), Hamburg, Germany, August 31 to September 3, 2016. http://smcnetwork.org/system/files/ SMC2016_submission_7.pdf

Bellia, A. (2009). Gli Strumenti Musicali Nei Reperti Del Museo Archeologico Regionale "Antonino Salinas" di Palermo. Roma: Aracne.

Bellia, A. (2012). Il Canto Delle Vergini Locresi. PisaRoma: Fabrizio Serra Editore.

Bellia, A. (2015). Relation of music to cultural identity in the colonies of West Greece: the case of Selinus. The Journal of Musicology, 1(6): 46-59.

Bellia, A. (2017). Su uno strumento musicale ri-trovato nel Museo Archeologico Regionale "Antonino Salinas di Palermo. Il frammento di aulos dal Santuario della Malophoros". Sicilia Antiqua, 14: 33-41.

Blinkenberg, C. S. (1931). Lindos, Fouilles de l'Acropole (1902-1914). Les Petits Objects. Berlin: De Gruyter.

Boardman, J. (1967). Excavations in Chios, 1952-1955. Greek Emporio. Athens: The British School of Archaeology at Athens.

Dawkins, R. M. (1939). The Sanctuary of Artemis Orthia at Sparta. London: Council of the Society for the promotion of Hellenic Studies.

Dunbabin, T. J. (1962). Perachora. The Sanctuaries of Hera Akraia and Limenia. Oxford: Clarendon Press.

Furtwängler, A. (1906). Aegina. Das Heiligtum der Aphaia. München: Akademie der Wissenschaften.

Greco, G. (1998). Da hera argiva a hera pestana. In I culti della Campania antica. Roma: G. Bretschneider, pp. 45-62.

Greco, G. (1999). Santuari extraurbani tra periferia cittadina e periferia indigena. In La colonisation grecque en Méditerranée occidentale. Roma: École française de Rome, pp. 231-47.

Hogarth, D. G. (1908). Excavations at Ephesus. The Archaic Artemisia. London: British Museum.

Landels, J. G. (1963). The Brauron aulos. Annual of the British School at Athens, 58: 116-19.

Landels, J. G. (1999). Music in Ancient Greece and Rome. London; New York, NY: Routledge. 
Marconi, C. (2013). Nuovi dati sui culti del settore meridionale del grande santuario urbano a selinus. Sicilia Antiqua, 10: 263-71.

Marconi, C. (2014). A new bone flute from selinus: music and spectacle in the main urban sanctuary of a Greek colony in the west. In Musica, culti e riti dei Greci d'Occidente. Roma-Pisa: Istituti Editoriali Poligrafici Internazionali, pp. 105-16.

Marconi, C. and Scahill, D. (2015). The "south building" in the main Urban Sanctuary of Selinus: a theatral structure? In The Architecture of the Ancient Greek Theatre. Aarhus: Aarhus University Press, pp. 281-94.

Micheloni, E., Pretto, N., Avanzini, F., Canazza, S., and Roda, A. (2016). Installazioni interattive per la valorizzazione di strumenti musicali antichi: il flauto di Pan del Museo di Scienze Archeologiche e d'Arte dell'Università degli Studi di Padova. In Proceedings of the XXI Colloquium of Musical Informatics, Cagliari, 28 September to 1 October 2016. http:// www.dei.unipd.it/ $\sim$ prettoni/paper/MicheloniPrettoetAl _Flauto_2016_CIM_XXI_Atti.pdf

Moustaka, A. (2001). Aulos und Auletik im archaischen Ionien. $\mathrm{Zu}$ einem Aulos aus dem Heraion von Samos.
In Festschcrift für Jörg Schäfer zum 75. Geburtstag am 25. April 2001. Würzburg: Ergon, pp. 131-6.

Psaroudakēs, S. (2002). The aulos of Argithea. OrientArchäologie, 10: 335-66.

Psaroudakēs, S. (2008). The auloi of Pydna. OrientArchäologie, 22: 197-216.

Psaroudakēs, S. (2013). The Dafnē aulos. Greek and Roman Musical Studies, 1: 93-121.

Psaroudakēs, S. (2014). The aulos of Poseidonia. In Musica, culti e riti nell'Occidente Greco, ed. by Angela Bellia, Pisa-Roma: Istituti editoriali e poligrafici internazionali.

West, M. L. (1992). Ancient Greek Music. Oxford: Clarendon Press.

Zoran, A. (2011). The 3D printed flute: digital fabrication and design of musical instruments. Journal of New Music Research, 40(4): 379-87.

\section{Notes}

$1 \mathrm{http}: / /$ cordis.europa.eu/result/rcn/203220_en.html 2 r:id="rId1" w:history="1" 